\title{
電力分野への高分子／ゴム材料の 適用状況と今後の課題
}

\section{Applications of Polymer/Rubber Materials to Electrical Power Apparatus and Cables}

水 谷 照 吉*

Teruyoshi MIZUTANI (Dept. of Electrical Engineering, Nagoya University)

The applications of polymers and rubber materials to electrical power apparatus and cables are reviewed. Polymers and rubber materials have been widely used as insulation and structure materials because of their excellent electrical/mechanical properties and easy manufacturing. They have played an important role to the development of highperformance apparatus in this half century. OF (Oil-Filled) cables are replaced with cross-linked polyethylene cables except UHV (Ultra High Voltage) AC and DC cables. Polymer insulators become popular in the field of outdoor insulators. Polymeric materials are also very important in transformers, rotating machines, GIS (Gas Insulated Switchgear) and so on.

On the other hand, polymers and rubber materials are rather weak at heat-resistance and ageing (degradation). Recent compact and high-performance power apparatus have strongly required the improved heat-resistance and long-term stability of polymers and rubber materials.

Key Word : Polymer, Rubber, Electric power apparatus, Power cable, Insulation

\section{1.は じめに}

20 世紀に入りエネルギー源としての電気の需要が急増 するにつれ，電力用機器は目覚ましい発展を遂げてきた. 特に, 第二次大戦後の各種合成高分子材料の開発と適用は 電力用機器やケーブルに飛躍的進歩をもたらした. 戦前は, 天然纎維(綿布, 紙など), 天然ゴム, マイカ, ガラスなど の天然材料が絶縁材料として利用されていたが, 現在では, エポキシ樹脂，ポリエチレンをはじめ多種多様の合成高分 子材料に置き換えられている。例えば，1947年に開発さ れたエポキシ樹脂は，1950年代はじめには電力分野への 適用が始まり，その優れた電気的，機械的性質はその後の 電力用機器の飛躍的発展に大きく貢献してきた.

1990 年代に入り, 電力系統の高電圧化 $(275 \mathrm{kV} \rightarrow 500 \mathrm{kV}$ $\rightarrow 1,000 \mathrm{kV}$ ) 新しい絶縁材料の出現も一段落し, 電力技 術も成熟技術になりつつある. しかし, 電力機器の小型 · 高性能化や低コスト化に対する要請は依然として強く, ま た, 機器の使用環境の多様化, 過酷化, 環境問題やリサイ クルへの対応など新たな要請がでてきている. かかる状況 のなかで, 高分子絶縁材料/ゴム材料に要求される性能も ますます高度化してきている.

本号の特集は「ゴムの電気特性, 最近の進歩」であるが, ゴム材料は高分子材料に属し，両者には絶縁材料として共
通する点が多い. また, 同一材料でも, ガラス転移温度を 境にして, 低温側はガラス状態, 高温側はゴム状態となり, 厳密に区分するのが難しいケースもある。ここでは，ゴム 材料を含む高分子絶縁材料を念頭に置き，電力分野への適 用状況と今後の課題について述べることにする.

\section{2. 高分子/ゴム材料の電力分野への適用状況}

高分子材料は, 成形加工が容易, 軽量, 多種多様な材料 の中から目的に応じて材料選定が可能で, 多方面で幅広く 実用化されている ${ }^{1)}$. 電力用機器やケーブルの分野でも, 高分子/ゴム材料は，その優れた電気的，機械的特性，軽 量, 成形加工の容易さ等の理由で, 広く実用化され, それ らの適用は多種多様にわたっている ${ }^{2,3)}$. ここでは, 紙面 の制限もあり, 構造が簡単でわかりやすい電力ケーブルと ポリマー碍子を中心に高分子/ゴム材料の適用状況と課題 について簡単に述べる(詳細は文献を参照 $\left.{ }^{1-3)}\right)$.

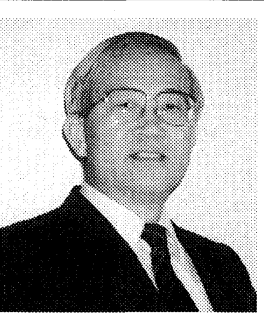

* 名古屋大学大学院工学研究科電気工学専攻 ( ₹ 464-8603 名古屋市千種区不老町) 教授, 工博. 昭和 39 年, 名古屋大学工学部電子工学 科卒業, 昭和 44 年, 同博士課程修了. 同年名 古屋大学助手. 昭和 62 年同教授, 現在に至る. 専門は, 誘電・絶縁材料, 有機エレクトロニ クス, 薄膜デバイス. 電気学会, 応用物理学 会, 高分子学会会員, IEEE Fellow 


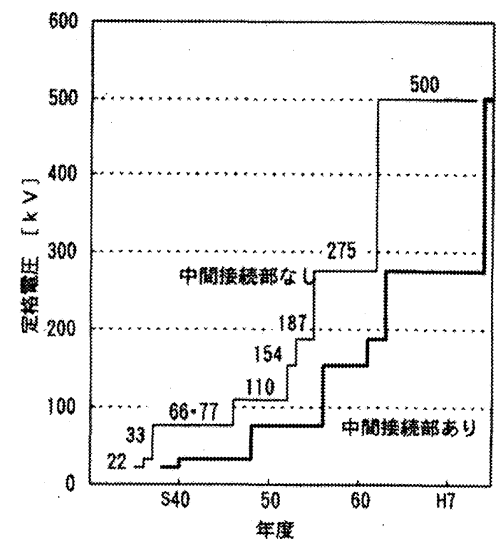

図 1 CV 電力ケーブルの高電圧化

\section{1 電カケーブル}

電力ケーブルとして現在まで広く用いられているもの は, 油浸紙を絶縁体とする OF (Oil-Filled) ケーブルと架 橋ポリエチレンを用いるCV (Cross-linked polyethylene Vinyl seathed)ケーブルがある. OFケーブルは 1920 年代 に開発され, その後絶縁紙の改善と合成絶縁油の開発等に より性能が改善され，1972年には AC500kVの OFケーブ ルが実用化されている．現在では，PP(ポリプロピレン) フィルムとクラフト紙をラミネートした半合成紙が普及 し，2000年には本州-四国の連系にDC500kVの海底 OF ケ ーブルが実用化された。 また，AC800kV用ケーブルの長 期実証試験も終了している ${ }^{4)}$. 欧州では, 高粘度の絶縁油 を用いる MI (Mass Impregnated) ケーブルが直流送電用に 使用されている5)。一方，油を使用しない架橋ポリエチレ ン絶縁のCV ケーブルが，1960年代に配電用として採用さ れて以来急速に高電圧化が進み, 1988 年と 2000 年に, 短 距離と長距離の AC500kV の線路に実用化されるに至っ た. 275-500kVクラスの直流ケーブルは, 現在 OFケーブ ルが使用されているが, 油による環境污染等の心配から, オイルレスの固体絶縁ケーブルの開発が進められている.

図 1 に国内の OFケーブル, CV ケーブルの最高使用電 圧の推移を示す，CVケーブルは，絶縁油を使用しないた め, 保守が容易 (メンテナンスフリー)で, 環境污染の心配 もないため, 現在では, 電力ケーブルの生産は, 高電圧用 の一部を除き, CVケーブルで占められている. 電力ケー ブルの歴史をみると, 1950〜1960 年代にかけて, ブチル ゴムや EP ゴムケーブルが一部出荷されたが, 現在ではほ とんど製造されていない.

ここで, 架橋ポリエチレン絶縁のCV ケーブルの高性能 化の流れを振り返るとともに今後の課題について述べてお く. CV ケーブルでは, 通常, ケーブル中の弱点部 (異物, ボイド，電極上の突起など) から絶縁破壊が始まり，トリ ーイング破壊が進展し全路破壊に至る。このため，CVケ ーブルの高性能化は, 製造工程の改善や品質管理によって, 異物, ボイド, 半導電層/ポリエチレン界面の突起やはく

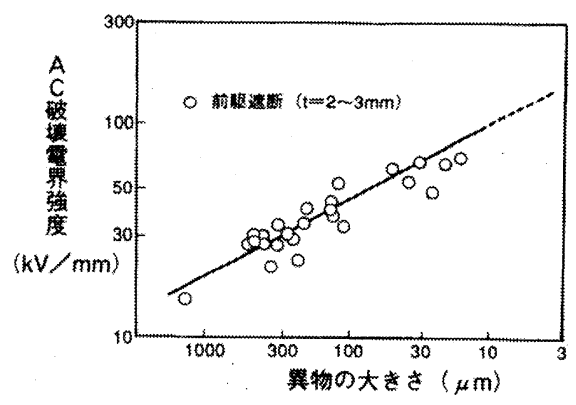

図 2 破壊強度と異物のサイズ

離を抑えることによって達成されてきたとも言える，原材 料やケーブル製造工程での異物の混入の防止, 半導電層用 のカーボン粒子の選定や内外半導電層と絶縁層の 3 層同時 押出による架橋ポリエチレンと半導電層の界面の欠陥除 去, 水蒸気架橋を廃してボイドや水分の除去に努めるとと もに，ケーブルの敷設工事に際しても欠陥部が生じないよ うに細心の注意が払われている．眓 2 はポリエチレン中の 異物の大きさと破壤電界を示したものであるが，混入する 異物の大きさを抑えることで，破壊電界が上昇しているこ とがよく分かる ${ }^{6)}$. かかる品質管理を通して, CV ケーブ ルの設計電界も, 当初の $6.6 \mathrm{kV}$ 用配電ケーブルの $1.1 \sim$ $1.4 \mathrm{kV} / \mathrm{mm}$ から最近の $500 \mathrm{kV}$ 送電ケーブルの 8.2 $10.7 \mathrm{kV} / \mathrm{mm}$ と大幅に改善されて, 高性能化が図られてき た. 2000 年に運転が開始された長距離 AC500kVCV ケー ブル (東京電力) では, $50 \mu \mathrm{m}$ 程度の微小異物の混入を抑 えるという厳しい品質管理のもとで製造されている. 長距 離の送電ケーブルで50 $\mu \mathrm{m}$ を越える異物を皆無にするこ とは至難の業であり，コストや生産性を考えると大きなサ イズの工業製品としてはこのあたりが限界であると思われ る.

今後更なる高性能化を図るためには, 使用する高分子材 料の本質的な絶縁破壊強度の改善が必要である.このため には，現在でも判然としない点の多い高分子絶縁材料であ るポリエチレンの絶縁破壊現象や絶縁劣化現象のメカニズ ムを解明するとともに，これらの基礎研究の成果に立脚し た合理的な材料設計や絶縁設計をすることが望まれる ${ }^{7,8)}$. ポリエチレンの物理/化学構造の制御や添加剤等による絶 縁破壊強度の改善, 弱点部を補強あるいは無力化するため の手法の探索 (自己修復機能が付与できれば理想的である が), トリーイング劣化や水トリー劣化の抑制法などを検 討する必要がある ${ }^{9}$. また, 現在の架橋ポリエチレンケー

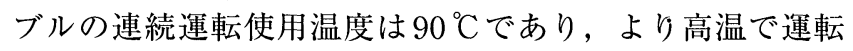
可能なケーブル材料の探索が行われている10). 高次構造 を制御したポリオレフィン材料やメタロセン触媒を用いて 立体構造の制御を行ったシンジオタクチック PP(ポリプロ ピレン)等が検討されている.

$\mathrm{CV}$ ケーブル本体以外の, ケーブル接続部 (中間接続部, 


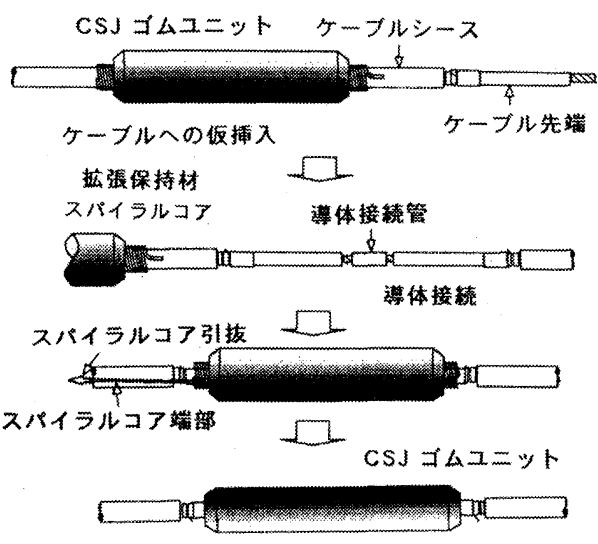

図 3 ワンピースゴムユニット形接続部の組立

終端接続部)にも，高分子/ゴム材料が使用されてい る $^{10,11)}$. CV ケーブルの接続部は, テープ巻形, プレハブ 形, モールド形に大別される。低圧クラスでは, 当初テー プ卷形であったが， $22,33 \mathrm{kV}$ クラスではセミプレハブ形 が，また，66，77kVクラスではワンピースゴムユニット 形が使用されている。ワンピースゴムユニット形の一つで あるCSJ (Cold Shrinkable Joint)を図 3 に示すが, 工場拡 張・常温収縮形のゴムユニットを挿入し, 導体接続後, 拡 張保持材を除去するだけでケーブルの接続が完了するもの で, 接続操作が簡単で工期の短縮が図れる. $154 \mathrm{kV}$ クラス では, プレハブ形が主流であり, 図 4 に示すように, エポ キシブロックの両側からストレスコーン(ゴム)で押さえる 構造になっている. $275 \mathrm{kV}$ より上のクラスでも, 従来の押 出モールド形 $(\mathrm{EMJ})$ に加えて, プレハブ形が採用されつ つある.プレハブ形やワンピースゴムユニット形の接続部 は施工の簡素化や工期の短縮のメリットがあり, 信頼性の 向上につれ，より高い電圧のクラスに実用化されつつある. ゴム材料としては, シリコーンゴム, EPR (Ethylene Propylene Rubber. 通常は, 架橋させるためDien系化合 物が導入されているのでEPDM と呼ぶことも多い)等が使 用されている. しかし, これらのケーブル接続部では, 機 械的圧力やゴムの収縮力で異種材料の界面の接触が保持さ れているだけであり, 界面への異物の混入や微小空隙の発 生による絶縁破壊の開始や面圧低下による絶縁性能の低下
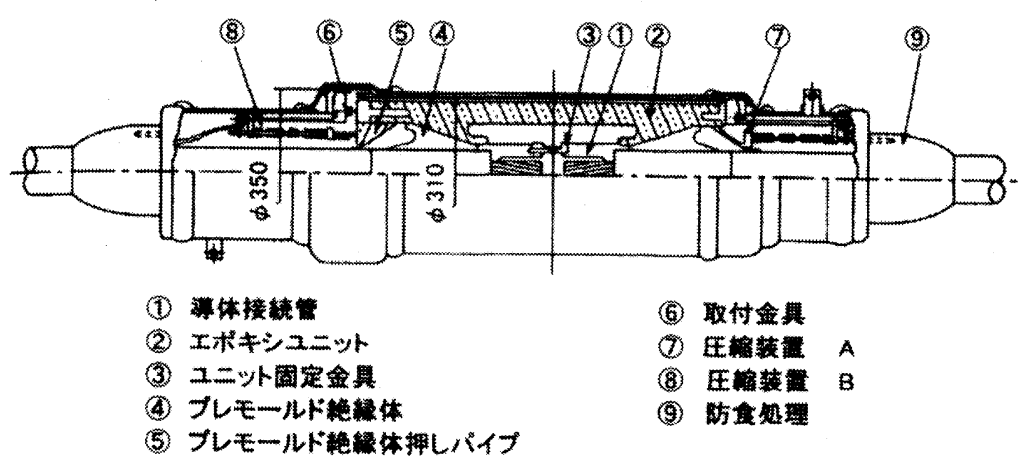

図 4 プレハブ形ケーブル接続部の構造
などの懸念があり，高電圧クラスへの実用化が進むにつれ， 界面に抢ける絶縁破壊現象の解明と絶縁性能の向上が望ま れている12).

\section{2 ポリマー碍子}

ポリマー碍子は, 1940 年代米国でのエポキシ樹脂製の 室内用碍子の使用に始まり，1960年代後半から 1970 年代 にかけて，軽量で猟銃の衝撃にも強いポリマー碍子が架空 送電線に適用されはじめ, 屋外用としても徐々に普及しつ つある ${ }^{13)}$. ポリマー碍子は, 従来の磁器碍子に比し, 製 造が容易, 軽量で運搬や取付が容易, 架空送電線のコンパ クト化にも役立つ等のメリットを有している。 ポリマー碍 子は, 図 5 に示すように, ガラス瀻維強化プラスチック (FRP)のコア, ゴム外被, 金具からなる，FRPで機械的 強度を確保し, 耐候性や耐トラッキング性に弱いFRPを ゴム外被によって保護するとともに，外被ゴムの撥水性を 利用して効果的に絶縁を確保している，材料による機能分 担をうまく利用した製品となっている。外被用ゴム材料と しては, シリコーンゴム, EPR (EPDM), 四フッ化エチ レン (PTFE), エチレン酢酸ビニル共重合体 (EVA)など が使用されている。 $100 \mathrm{kV}$ 以上の送電線には前二者が用い られている。ポリマー碍子は, 架空送電線用の懸垂碍子の みならず, 電力用機器のブッシング, ハウジング用碍管と して普及しつつある，成形加工が容易で軽量であるポリマ 一碍子は複雑な形状への対応が容易であり，また地震災害 にも強い.

上述したように，高分子/ゴム材料は，無機材料に比し， 耐候性, 耐トラッキングなどに劣り, 経年劣化が問題とな る. 特に, 屋外で使用する場合には, 材料の劣化現象の把 握と長期安定性の改善が重要な課題となる．外被ゴムの性 能を示す指標の一つに撥水性がある，通常の高分子/ゴム 材料は経年劣化とともに撥水性が低下するが, シリコーン ゴムは材料内部から低分子シリコーンが表面にしみ出し, 長期にわたって表面の撥水性を保持し，また，表面が污損 されても低分子シリコーンのしみ出しで撥水性が回復する 特性を持っている.これがシリコーンゴムが屋外碍子の外 被ゴムとして多用される理由である ${ }^{12,13)}$.

しかし, ポリマー碍子は, その単純な構造に もかかわらず，高分子/ゴム材料と複合材料の 複雑さを併せ持っており, その経年劣化現象は 複雑で使用環境によっても大きく左右され，ま だ国際標準となる評価試験法 (材料評価法, 加 速劣化試験法等) も十分確立されていない状況 にある ${ }^{13)}$. FRPの絶縁破壞に及ぼすエポキシ/ ガラス界面の影響, FRP(ガラス繊維)の脆性破 壊, シリコーンゴムの撥水性と絶縁特性の関係, 外被ゴム/FRP界面の現象，シリコーンゴム/ 充てん材界面の現象, 污損状況や機械的ストレ 

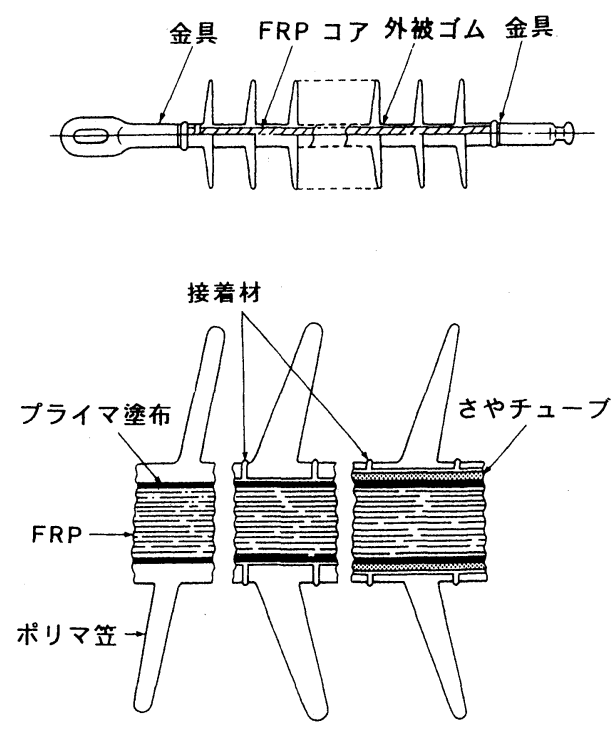

図 5 ポリマー碍子の構造

スとポリマー碍子の絶縁劣化特性との関連等に関する研究 が活発に進められており, IEEE Trans., 電気学会論文誌, 関連国際会議等で多くの論文が報告されている ${ }^{3,12-14)}$.

\section{3 電力用機器}

電力用機器への高分子/ゴム材料の適用は絶縁材料から 構造材まで多岐にわたっている。ここでは，主な電力用機 器の高分子絶縁材料について簡単に触れておくことにす る.

変圧器では, 紙と鉱油の油浸絶縁を用いる油入変圧器, $\mathrm{SF}_{6}$ ガス絶縁変圧器, シリコーン油とアラミッド紙を用い た難燃性／耐熱性変圧器, オイルレスのモールド変圧器な ど用途に応じて絶縁材料が使い分けられている．高電圧／ 大容量の大型変圧器は油入変圧器が主流であるが, 最近は, 都市部の地下変電所を中心に, 不燃性のガス絶縁変圧器が $275 \mathrm{kV}, 300 \mathrm{MVA}$ A ラまで大容量化しつつある。また， 巻線をエポキシ樹脂で固めたオイルレスのモールド変圧器 がビル用電源として普及している.

回転機絶縁としては，高電圧用はマイカ絶縁，低電圧用 はフィルム材やエナメル絶縁が使用されている．高分子材 料は耐コロナ放電性に劣るため, 高圧用は耐コロナ性に優 れる無機材料のマイカを使用せざるを得ない：しかし，マ イカ絶縁と言っても, マイカテープを導体に巻いた後, 低 粘度のエポキシ樹脂を含浸させる真空加圧含浸方式と，あ らかじめマイカテープに樹脂を含浸し半硬化させたプリプ レグテープを導体に巻き加熱成形するプリプレグ方式があ り，いずれも高分子材料とマイカの併用である，その他， コンデンサ絶縁用の高分子フィルム (ポリプロピレンフィ ルムなど), ガス絶縁機器用のエポキシスペーサ, 開閉器 等の注型部品など, 高分子材料は電力用機器に広く実用化 されている.

上述のように，高分子/ゴム材料の長所をうまく生かし つつ，その短所を複合化等でカバーして利用している. 例
えば，ポリマー碍子に扔ける FRP と外被ゴムのように複 合化による機能分担で高性能化を達成している。また，モ ールド変圧器, ブッシング，スペーサとして広く使用され ているエポキシモールド絶縁に使用される沉用のビスフェ ノール A 形エポキシ樹脂は熱変形温度が $105{ }^{\circ} \mathrm{C}$ と低く, ま た熱衝撃や機械的ストレスでクラックが入りやすいが，各 種充てん材 (シリカ, アルミナなど) と併用してこの欠点を カバーしている．屋外使用には耐候性に優れる環状脂肪族 系エポキシ樹脂が用いられることもある.

このように，高分子/ゴム材料は電力分野で幅広く実用 化され,電力用機器やケーブルの高性能化に貢献している. 単に使用量とその種類が多いと言うだけでなく，機器やケ ーブルの性能と寿命に直接関与する場合が多く重要な材料 である．材料の選定と適用の適否が製品の良否を左右する ため, 多種多様な材料の中から最適な材料, 複合化の組み 合わせを選定するとともに，その電気的・機械的特性，劣 化現象を把握しておくことが重要となる．電力分野以外の 分野でも, プリント基板, 各種フレキシブル配線, 電子部 品, IC の樹脂パッケージ, 各種スイッチ・コンセント, 電気・電子機器の構造材など, 電気電子分野への高分子, ゴム材料の適用は挙げればきりがない ${ }^{1,2}$.

\section{3. 高分子/ゴム材料の特徵と今後の課題}

高分子/ゴム材料が電力分野で広く実用化される理由と して，（1）成形加工が容易，（2）比較的低コスト，（3）軽 量，（4）多種多様の材料がある，(5）分子設計・合成技術 で新素材の開発が容易，（6）充てん材等との複合化等によ り, 幅広い特性の材料開発が可能，などが挙げられる。し かしながら，無機材料に比し，一般に，高分子/ゴム材料 は耐熱性，耐候性，耐トラッキング性等に劣り，経年劣化 しやすいなどの欠点もある.

21 世紀を迎え, 電力用機器の小型 - 高性能化の要求, 環境問題(環境污染，リサイクル，省資源等）や国際競争 (低コスト化)などへの対応など, 電力用機器に対する要望 は最近ますます厳しくなりつつあり，高分子/ゴム材料に 対しても一層の高性能化, 多機能化, 低コス卜化が求めら れている. 電力用機器・ケーブル分野の今後の課題と高分 子/ゴム材料への要望は, 要約すると表 1 のようになる.

ここで，もう少し具体的に高分子/ゴム材料に対する今 後の研究課題について述べておく.

（1）劣化現象の解明と絶縁診断法の確立 電力用機器の 寿命は使用されている高分子/ゴム材料の劣化に起因する 場合が多い，劣化要因には，熱，機械的ストレス，電気的 ストレス(放電劣化，トリーイング劣化，トラッキング劣 化等), 環境条件(紫外線, 放射線, 湿度等) などが挙げら れ，これらの要因が重なり，劣化を加速する複合劣化とな る場合も多い ${ }^{15)}$. 高分子/ゴム材料の劣化現象, 特に複合 
表 1 電力分野の今後の課題と高分子/ゴム材料への要望

\begin{tabular}{|c|c|}
\hline 電力分野の今後の課題 & 高分子／ゴム材料への要望 \\
\hline $\begin{array}{l}\text { 高品質な電力供給 } \\
\text { 電力機器の高性能化 } \\
\text { コンパクト化・低コスト化 }\end{array}$ & $\begin{array}{l}\text { 材料の高性能化, 長期安定性の } \\
\text { 改善 } \\
\text { 耐熱性材料, 複合材料, } \\
\text { 新素材 }\end{array}$ \\
\hline $\begin{array}{l}\text { 使用環境の多様化 } \\
\text { 高温, 低温, 宇宙, 直流送電 }\end{array}$ & $\begin{array}{l}\text { 耐熱性材料, 低温材料, 耐放射 } \\
\text { 線性材料, 直流絶縁材料 }\end{array}$ \\
\hline システム化・online 絶縁監視 & 材料の多機能化, センサ組込 \\
\hline 環境・リサイクル & $\begin{array}{l}\text { 不燃性, 無毒性, 電磁シールド, } \\
\text { 防音 } \\
\text { 環境にやさしい材料（生分解材 } \\
\text { 料） } \\
\text { リサイクルが容易な材料 }\end{array}$ \\
\hline
\end{tabular}

劣化現象に関しては判然としない点が多く，これらの解明 と劣化抑止対策の確立は重要な課題である．寿命特性 $(\mathrm{V}-$ $\mathrm{t}$ 特性)を正しく把握し, 合理的な絶縁設計を可能にすると ともに，事故につながる欠陥の検出や事故の事前予知をす るための絶縁診断法を確立することが望まれる.

（2）高分子/ゴム材料の電気特性の解明と絶縁性能の改善 高分子/ゴム材料の電気特性 (高電界電気伝導, 絶縁破壊) は材料の複雑な物理/化学構造や添加剤, 充てん材などに よって影響され，まだ十分把握されていない，物理/化学 構造, 添加剂, 充てん材等が絶縁破壊に及ぼす影響を明ら かにし, 絶縁性能の改善につなげることが望まれる.

（3）耐熱性の改善 電力用機器の小型・高性能化は運転 温度の上昇を伴う場合が多く，高分子/ゴム材料の耐熱性 の向上は機器の小型・高性能化と密接に関連している. 耐 熱性高分子として注目されているスーパーエンプラの中に は，ポリイミド，ポリアミドイミド, PEEK，フッ素樹脂

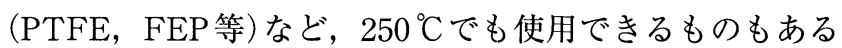
が16)，低コストで耐熱性に優れた材料の開発に対する要 望は強い．充てん材等で耐熱特性を改善することも一つの 方法である. 一方, 高温超伝導材料を使用する電力機器や ケーブルの開発が進むと, 低温特性のすぐれた材料(例え ば，低温でもある程度の柔軟性をもつ材料)に対する要求 も強まると思われる。

（4）複合材料と界面現象高分子/ゴム材料は充てん材 と複合して使用される場合が多い。機能分担により高性能 な材料ができる反面, 異種材料界面のはく離や膨張率の差 によるクラックや機械的ストレスの発生などにより，絶縁 性能の低下を引き起こす．充てん材に表面処理を施し樹脂 との接着を強化したり，充てん材の形状や製造工程を工夫 して均質化を図るなどの努力が払われている。最近は，ナ ノ粒子を用いたナノコンポジットを電気絶縁材料に応用す
る試みも始まっており，従来の複合材料とは異なった優れ た性能の発現が期待されている。また，実際の絶縁システ ムでは, ケーブル接合部やポリマー碍子のように, 異種絶 縁材料の大きな界面(例えば, 図 4,5の工ポキシ樹脂と ゴムの界面)も存在する，かかる絶縁システムでは，絶縁 破壊が界面で発生し進展することが多い。界面における絶 縁破壊現象を明らかにし, 複合絶縁系の高性能化を図るこ とも重要な課題である.

\section{4.むす す}

高分子/ゴム材料は成型加工が容易で電気的・機械的特 性にも優れており, 電力分野にも幅広く実用化されている. しかし, 最近の電力機器やケーブルに対する一層の高性能 化, 低コスト化が求められている状況のなかで, 高分子/ ゴム材料に対する高性能化の要望も厳しくなってきてい る.ここでは，高分子/ゴム材料の電力分野への適用状況 と今後の課題について簡単にまとめてみた.この分野は高 分子化学と電気工学の境界領域であり, 両分野の研究者・ 技術者の協力により, 高分子/ゴム材料のもつ弱点耐熱性, 耐劣化性）をうまくカバーした新素材の開発や複合化など を通して, 電力用機器やケーブルの一層の高性能化が達成 されることを期待している.

\section{参 考 文 献}

1) 例えば，プラスチック材料活用辞典，産業調査会 (2001)

2 ) Shugg, W. T. : "Handbook of Electrical and Electronic Insulating Materials" 2nd Ed., IEEE Press, New York (1995)

3 ）電気学会技術報告 907 号「電気・電子絶縁システムの学術・技 術研究の将来展望」(2002)

4 ) Couderc, D. et al. : CIGRE paper 21/22-04(1996)

5 ）電気学会技術報告 745 号「直流ケーブルの技術動向と今後の課 題」(1999)

6 ) 古川他：電気学会誘電絶縁材料研究会, DEI-92-8(1992)

7 ) 水谷：電学論, 112-A, 166(1992)

8 ）電気学会技術報告 304 号「高分子絶縁材料の絶縁破壊現象」 (1989)

9 ) 電気学会技術報告 854 号「トリーイング劣化機構と高分子高次 構造の影響」(2002)

10）電気学会技術報告 858 号「OFケーブルおよびC V ケーブルにお ける高温性能とその支配要因」(2001)

11）電気学会技術報告 592 号「地中配電ケーブル用接続部の技術動 向」(1996)

12）電気学会技術報告 694 号「複合絶縁材料の界面現象とその評価」 (1998)

13) Halls, J. F. : IEEE Trans. on Power Delivery 8, 325(1993)

14) CIGRE Brochure No.142, "Natural and Artificial Ageing and Pollution Testing of Polymeric Insulators" (1999)

15）電気学会技術報告 225 号「絶縁システム複合要因劣化に関する 研究の現状」(1986)

16）水谷：電気学会雑誌，110，360(1990) 